\title{
Payrolling - outsourcing in human resource management
}

\author{
Agnieszka Herdan \\ Greenwich University, London \\ Magdalena M. Stuss \\ Jagiellonian University in Krakow
}

\section{Introduction}

Globalization and the free transfer of resources, capital and workforce drives outsourcing and has increased its popularity. According to Aird and Sappenfield ${ }^{1}$ the current and future trends of outsourcing strongly depends on the development of Information Technology. Transferring a company's operation to an external provider has been well-known and used for many years by many multinational companies as a part of their strategies to minimise operating costs. With increasing competition and scarce resources, companies are looking for new more efficient ways of delivering various functions and operations. In recent years one of the most outsourced function part of Human Resource Management is payrolling.

This paper investigates the opportunities provided by outsourcing the payrolling function. Firstly, the outsourcing will be defined, and its benefits discussed. This will be followed by an analysis of payrolling within HRM outsourcing. And finally, the benefits of outsourcing of the payrolling function will be presented.

The research methodology adopted in this paper started from a basic literature search focusing on the intended research objectives. The following sources were utilized: ProQuest, Emerald, SCOPUS to gain access to publications with an international scope. A selection was chosen on the basis of the following key words: outsourcing, outsourcing HR, personnel outsourcing and payrolling.

1 C.L. Aird, D. Sappenfield, IT the 'Enabler' of Global Sourcing, "Financial Executive" 2009, vol. 25, issue 5, pp. 62-65. 
In the subsequent stage, the literature review was expanded to include Polish scientific publications, including monographs and papers reviewed in the leading Polish journals collected in the Library of the Jagiellonian University ${ }^{2}$.

The accumulated sources were narrowed by excluding papers such as communiques, conference presentations and book reviews. Finally, content analysis of the abstracts was conducted and focussed on the area of management science. The references obtained were subsequently subjected to an in-depth analysis of the content in the systemization of the literature. The methodology adopted facilitated the collection of sources that are significant for further analysis.

\section{What is outsourcing?}

The word outsourcing derives from the English expression "outsider-resource-using”, which means use of external resources. Many publications define outsourcing as a part of business areas where they have expertise and then place their resources accordingly to achieve a competitive advantage ${ }^{3}$.

According to Trocki ${ }^{4}$, outsourcing should be understood as extracting certain functions from the organizational structure of a company and transferring them for execution to an external entity. He stresses that such actions inevitably affect the organization and substantially changes the companies' structures. On the other

2 The Jagiellonian Library has the obligation of collecting the published works of Polish scientists in its statutory aims, thus it is one of the largest and most valid sources for the purposes of reviewing Polish references.

3 See: R.E. Miles, C. Snow, Designing strategic human resources systems, "Organizational Dynamics" 1984, vol. 13, no. 1, pp. 36-52; N. Rajagopalan, S. Finkelstein, Effects of strategic group membership and environmental change in senior management reward systems, "Strategic Management Journal” 1992, vol. 13, no. S1, pp. 127-141; F.C. Santos, Integration of human resource management and competitive priorities of manufacturing strategy, "International Journal of Operations \& Production Management" 2000, vol. 20, no. 5, pp. 610-628; D.P. Lepak, K.M. Bartol, N. Erhardt, A contingency framework for the delivery of HR practices, "Human Resource Management Review" 2005, vol. 15, no. 2, pp. 139-159; H. Abdul-Halim, N. Che-Ha, A. Geare, The influence of business strategy on the decision to outsource human resource activities: a study of Malaysian manufacturing organizations, "Journal of Human Resource Costing and Accounting" 2009, vol. 13, no. 4, pp. 274-293; H.A. Shih, Y.H. Chiang, Exploring the effectiveness of outsourcing recruiting and training activities, and the prospector strategy's moderating effect, "The International Journal of Human Resource Management” 2011, vol. 22, no. 1, pp. 163-180; R. Gonzalez, J. Llopis, J. Gasco, Outsourcing and strategy in Spanish town halls: a field study, "Management Decision" 2013, vol. 51, no. 1, pp. 97-119.

4 M. Trocki, Metoda restrukturyzacji działalności gospodarczej, Polskie Wydawnictwo Ekonomiczne, Warszawa 2001. 
hand, Penc ${ }^{5}$ defines outsourcing as the use of comprehensive services that are a combination of a variety of services provided by external contractors (bidders).

One of the most popular and most commonly used definitions is the one developed by Greaver's. He describes outsourcing as "the act of transferring some of an organization's recurring internal activities and decision rights to outside providers, as set forth in a contract"6. In addition, Lysons and Gillinham7 highlight that 'outsourcing requires strategic use of external resources for the implementation of activities that in the past has been traditionally conducted by its own staff using internal resources of the company'. So outsourcing is a management strategy that involves the separation of the organizational structure of certain auxiliary functions and entrusting their implementation to external specialised organisation.

Moreover, a number of authors ${ }^{8}$ define outsourcing as distributing one or many of the business processes to an outside vendor. The firm that provides outsourcing services is given ownership of one or more operational activities of the business ${ }^{9}$, so transferring activities traditionally done within a firm to third party providers within the country or "off-shore" 10 . The companies quite often discontinue inhouse activities to minimize the operational cost ${ }^{11}$.

As companies look for maximization of operational efficiency by focusing on the core competencies, the numbers of organization that heavily relay on outside provider increases ${ }^{12}$.

5 J. Penc, Encyklopedia zarzq̨dzania, Agencja Wydawnicza Placet, Warszawa 2008.

6 M.F. Greaver, Strategic Outsourcing. A Structured Approach to Outsourcing Decisions and Initiatives, Amacom, New York 1999, p. 7.

7 K. Lysons, M. Gillingham, Purchasing and supply chain management, Pearson, Prentice Hall, Harlow 2012.

8 See: A. Sharma, P. Loh, Emerging Trends in Sourcing of business services, "Business Process Management Journal" 2009, vol. 15, no. 2, pp. 149-165; A. Kakabadse, N. Kakabadse, Sourcing: new face to economies of scale and the emergence of new organizational forms, "Knowledge and Process Management” 2000, vol. 7, no. 2, pp. 107-118; W. Scott-Jackson, T. Newham, M. Gurney, HR Outsourcing: the Key Decisions, Chartered Institute of Personnel and Development, London 2005.

9 A. Mehta et al., Challenges and Opportunities of Business Process Outsourcing in India, "Journal of Labour Research" 2006, vol. 27, issue 3, pp. 323-338.

10 F. Sen, M. Shiel, From business process outsourcing (BPO) to knowledge process outsourcing (KPO): Some issues, "Human Systems Management" 2006, no. 25, pp. 145-155.

11 B.S. Klaas, J.A. McClendon, T.W. Gainey, Outsourcing: the impact of organizational characteristics, "Human Resource Management" 2001, vol. 40, no. 2, pp. 125-138.

12 A. Mehta et al., Challenges and Opportunities... 
According to Kremic et al. ${ }^{13}$ outsourcing is driven by three major factors: cost, strategy and politics. Costs and strategy are typical drivers for private industry, as political agendas are usually the main factor in public organizations ${ }^{14}$. Bers $^{15}$ as well as Harler ${ }^{16}$ claim that the cost factor occurs when providers can offer service for a lower price that already include provider's overhead, profit, and transaction costs. Reducing cost via outsourcing can be very significant. Domberger and Fernandez ${ }^{17}$ claim that outsourcing of cleaning services saved an average of 46 percent of in-house activity. In addition, many companies look for saving indirect costs by reducing the number of employees as this will lead to less infrastructure and support systems ${ }^{18}$.

Lately one of the main reasons for outsourcing is the strategic factor such as core competence and flexibility as this can improve business performance on numerous dimensions ${ }^{19}$. The most emphasised motive for outsourcing is the opportunity for the organization to concentrate on its core competencies due to increased competition and scarce resources ${ }^{20}$.

\section{Payrolling within HR outsourcing}

The most outsourced function is Human Resource Management (HRM) 21 . HRM outsourcing is a process in which the human resource activities of an organization are contracted to an external provider so the company can focus on the organization's core competencies. In other words, it is entrusting an external

13 T. Kremic, O.I. Tukeld, W.O. Rom, Outsourcing decision support: a survey of benefits, risks, and decision factors, "Supply Chain Management: An International Journal" 2006, vol. 11, no. 6, pp. 467-482.

14 A. Kakabadse, N. Kakabadse, Sourcing: new face...

15 J.S. Bers, Outsourcing: a deal or dilemma for FMs?, "Facilities Design \& Management" 1992, vol. 11, no. 3, pp. 54-57.

16 C. Harler, Opting for outsourcing, "Business Communications Review" 2000, vol. 30, no. 7, pp. 56-61.

17 S. Domberger, P. Fernandez, Public-private partnerships for service delivery, "Business Strategy Review" 1999, vol. 10, no. 4, pp. 29-39.

18 R. Fontes, The outsource option, "Folio: The Magazine for Magazine Management" 2000, pp. 112-115.

19 See: L. Wright, Market viewpoint: outsourcing is a no-claims bonus, "Insurance Brokers' Monthly \& Insurance Adviser" 2001, vol. 51, no. 1, pp. 12-15; J.B. Quinn, Strategic outsourcing: leveraging knowledge capabilities, "Sloan Management Review" 1999, vol. 40, no. 4, pp. 9-21.

20 G. Avery, Outsourcing public health laboratory services: a blueprint for determining whether to privatize and how, "Public Administration Review" 2000, vol. 60, no. 4, pp. 330-337.

21 K. Kalinowska, Outsourcing jako metoda zarządzania przedsiębiorstwem, "Zeszyty Naukowe Polityki Europejskie, Finanse i Marketing” 2010, nr 3(52), pp. 253-264. 
company the responsibility for part or all of the human resources management processes including providing IT system that supports those processes. Frequently HR functions are complex and time consuming and if those activities can be delivered by an external company, the effectiveness of the business can be enhanced by focussing on what the organization is best at ${ }^{22}$. It will also improve the flexibility and adaptability of the organization to the rapidly changing business environment ${ }^{23}$.

Recently, one of the fastest growing areas of HR outsourcing is outsourcing remuneration systems known as payrolling 24 . Payrolling is a business service that provides payroll processing, pay-check writing, payroll tax administration and all legal matters relating to hiring employees ${ }^{25}$. A company offering a payrolling package is responsible for collecting and remitting payroll taxes and for paying all the employer taxes. The aim of the Payrolling Company is to provide either a part or the entire payroll function. In practice, this means efficient processing of a large amount of data obtained from the customer. Activities under payrolling are adapted to the individual needs of the client. Mostly they include the creation of a payroll list, the calculation of wages/salaries, creating payroll databases, the preparation of payslips and monthly statistical reports ${ }^{26}$.

22 See: J. Delmotte, L. Sels, HR outsourcing: threat or opportunity?, "Personnel Review" 2008, vol. 37, no. 5, pp. 543-563; C. Sheehan, B.K. Cooper, HRM outsourcing: the impact of organisational size and HRM strategic involvement, "Personnel Review" 2011, vol. 40, no. 6 , pp. 742-760.

23 See: F.L. Cooke, J. Shen, A. McBride, Outsourcing HR as a competitive strategy? A literature review and assessment of implications, "Human Resource Management" 2005, vol. 44, no. 4, pp. 413-432; T. Nesheim, K. Olsen, A.L. Kalleberg, Externalizing the core: firms' use of employment intermediaries in the information and communication technology industries, "Human Resource Management" 2007, vol. 46, no. 2, pp. 247-264; M.M. Stuss, Payrolling jako narzędzie rozwoju ZZL we współczesnych przedsiębiorstwach, [in:] J. Engelhardt, M. BrojakTrzaskowska, M. Porada-Rochoń (eds), Nowoczesne przedsiębiorstwo, "Zeszyty Naukowe Uniwersytetu Szczecińskiego" 2009, no. 572, pp. 275-281.

24 See: M. Dickmann, S. Tyson, Outsourcing payroll: beyond transaction-cost economics, "Personnel Review" 2005, vol. 34, no. 4, pp. 451-467; D. Shelgren, Why HR outsourcing continues to expand, "Employment Relations Today" 2004, vol. 31, no. 2, pp. 47-53; C. Sheehan, B.K. Cooper, HRM outsourcing...; T. Nesheim, R. Rørvik, Exploring dilemmas in the relation between temporary help agencies and customer firms, "Personnel Review" 2013, vol. 42, no. 1, pp. 67-82; R. Remont, Outsourcing HR - moda czy tendencja biznesowa?, 2017, http:// www.outsourcing.com.pl (accessed: 8.02.2017).

25 C. Mise, Payroll and HR outsourcing. Is it viable solution for tour organisation, CMA management, 2001 March, pp. 30-32, https://www.cmamanagement.com/uploaddocs/cma/websi te//Home.asp (accessed: 6.02.2019).

26 See: D. Gotterdello, M. Valverde, Human resources management outsourcing in Spanish firms: evaluation over time and implication for devolution, "Intangible Capital” 2018, vol. 14(1), pp. 56-73. 
Payrolling as outsourcing service can be delivered in three forms ${ }^{27}$ :

- Application Maintenance Outsourcing (AMO) - a third-party provides operating system and support all its users of the HR application, including any necessary updates;

- Managed Payroll Services (MPS) - outsourcing company has been entrusted with the responsibility for a wider administration of payroll of the employees;

- Business Process Outsourcing (BPO) - outsourcing company provide all processes of the administration of personnel and payroll, or a group of other HR business processes.

The outsourcing contracts usually include a mix of the above three services ${ }^{28}$. It should be noted that in Europe as well as in Poland, unlike in the US, BPO is a rather uncommon practice.

An increasing number of companies use payrolling services to reduce company risks as well as reduce the administrative workload associated with being an employer. Payrolling leads to a reduction of administrative and personnel costs. Some experts already highlight that cost-effectiveness of payrolling can be achieved even in small companies with fewer than 50 employees $^{29}$. Of course, the effectiveness of payrolling increases with the larger number of employees.

In Poland, HR outsourcing has a small share of the market. In addition, various analysis show that modern HRM outsourcing products such as mentoring, managerial coaching, training and development that are commonly used in the west are almost completely neglected by Polish companies ${ }^{30}$. The growing interest in payrolling does not mean that outsourcing payrolling does not have its flaws, however it should be noted the advantages outweigh its disadvantages.

\section{Characteristics of outsourcing payrolling}

Nowadays, outsourcing the payroll has become an option that many organisations are looking for ${ }^{31}$.

27 C. Brooks, Choosing a Payroll Service: A Buying Guide for Businesses, 2017, March 17, http:// www.businessnewsdaily.com/7477-choosing-payroll-service.html\#sthash.jlkXJBly.dpuf (accessed: 15.11.2019).

28 R. Remont, Outsourcing HR...

29 M.M. Stuss, Payrolling jako narzędzie rozwoju ZZL...

30 Ibidem.

31 See: K.M. Gilley, C.R. Greer, A. Rasheed, Human resource outsourcing and organizational performance in manufacturing firms, "Journal of Business Research" 2004, vol. 57, no. 3, pp. 232-240; M. Oshima, T. Kao, J. Tower, Achieving post-outsourcing success, "People and Strategy" 2005, vol. 28, no. 2, p. 7; B. Duggan, G. Croy, Should you outsource recruitment?, "Supply Management" 2004, vol. 3, no. 7, pp. 26-27; H. John, HR outsourcing in operation: 
$\mathrm{ADP}^{32}$ stress that one in three small businesses receive tax penalties for the miscalculation of tax obligations. Research shows that in companies with up to 20 employees two full days per month need to be solely dedicated to the payroll function. In addition, small businesses spend over $\$ 1,300$ per employee on tax compliance $^{33}$. So they look to minimise those costs. Furthermore, large companies search for various options to make their payroll function cost-effective and efficient ${ }^{34}$.

Businesses can outsource their entire payroll function or decide on a specific tailored service provided by an external supplier. The vendor usually provides 3 three sets of payroll services ${ }^{35}$ :

- Administration Payroll Services:

- Data collection and gross-to-net payroll calculation;

- Administration and archiving of personal files/documents;

- Statutory and management reporting;

- Preparation and distribution of payslips;

- Payments realization via trustee account;

- Issuing certificates or any other employee documents;

- Online employee support;

- Representation during payroll audits/inspections;

- Payroll consultancy:

- Payroll Taxes \& Employment Regulations;

- Employee registration;

- Labour Law consultancy;

- Personal income tax \& social security advisory Non-resident tax consultancy;

- Expats: work \& residence permits, relocation support;

- Employee benefits - budget optimization;

- Revision/preparation of labour contracts, suplements and termination documents;

critical success factors, "Human Resource Management International Digest" 2005, vol. 13, no. 3, pp. 39-42; J. Marquez, Reducing costs a sore subject at HRO meeting, "Workforce Management" 2007, vol. 86, no. 9, pp. 7-8.

32 ADP, 2019, https://www.adp.com (accessed: 8.12.2019).

33 N.V. Crain, W.M. Crain, The impact of regulatory costs on small firms, US Small Business Administration, Office of Advocacy, 2010, September, https://www.sba.gov/sites/default/files /The\%20Impact\%20of\%20Regulatory\%20Costs\%20on\%20Small\%20Firms\%20(Full).pdf (accessed: 8.02.2017).

34 R. Parish, Modern payroll outsourcing. A success story, "Nursing Home Magazine", 28 January 2008, https://www.iadvanceseniorcare.com/modern-payroll-outsourcing-a-success -story/ (accessed: 6.02.2019).

35 IRIS, http://www.iris.co.uk/insight/iris-rti-managed-payroll-service/ (accessed: 20.12.2019). 
- Drafting internal regulations or any other local or group procedures related to employees;

- Establishment, registrations and other corporate services;

- Payroll Platform for Management \& Employees Payroll \& HR online document management:

- Online approval workflow for payroll \& HR documents;

- Time \& attendance;

- Absences management;

- Electronic payslips;

- Electronic archive of payroll and HR related documents;

- Payroll inquiry online handling, hotline service.

By outsourcing the payroll function, the company can focus on their core activities and obtain the following benefits ${ }^{36}$ :

- Minimise legislative changes and related stress - the responsibility of managing legislative changes is transferred to the outsourcing company.

- Save time and effort - payroll is an essential function of any business, but it can be a time-consuming task. Outsourcing this activity to an external provider allows company staff to focus on important business tasks. Reduce costs - running a payroll department can be expensive for some companies. According to TotalJobs.com ${ }^{37}$, the average Payroll Manager cost at least $£ 32,500$ per year and the average cost of printing and distributing payslips is $£ 1.75$ per employee. In addition, a company needs to consider purchasing payroll software and regular training for legislative updates. According to Surepayroll ${ }^{38}$ a company that has around 10 employees will usually spend at least $\$ 2,600$ per year in direct labour costs associated with payroll.

- Utilise knowledge of experienced payroll professionals - the company needs at least one or two designated members of staff operating payroll function. The business needs to invest time and financial resources to get those members of staff trained on a regular basis and update them on the latest legislative changes. Using outsourcing gives a company access to a much wider range of knowledge, experience and expertise from payroll dedicated professionals.

- Improve efficiency - outsourcing payroll gives access to a huge variety of reports customised to suit numerous needs of different businesses. These can help in various areas of the business and streamline internal processes. Some of the reporting function include payroll summaries, payroll control report,

36 Ibidem.

37 TotalJobs, www.Total Jobs.com (accessed: 21.12.2019).

38 Surepayroll, www.surepayroll.com (accessed: 11.12.2019). 
tax payment, summary report, payments to third parties, general ledger reports and payroll analysis.

The cost of payroll services will differ depending on the type, size and scale of the software and service included in the package. Companies can approach the payroll function in three ways ${ }^{39}$ :

- In House - typically used by those business that have fewer than 5 members of staff as well as some large companies that have a fully functioning accounting department. It usually requires only the purchase of a software package and some expertise regarding payroll. For some packages the company will need to pay a monthly fee that can range from $£ 20$ per month to up to $£ 500$, while other deals can consist of one-off payments that can run into tens of thousands of pounds. One of the most famous In House Providers is SAGE.

- Partly Managed - these packages allow companies to administer the front end of the payroll function while allowing a professional service to deal with the more complex and time-consuming data processing. This is the most popular approach for those companies that want to maintain some control and oversight of the payroll while keeping their staff focused on the jobs they were hired to do.

- Fully Managed - the company outsources the entire payroll function to the external provider. There are many firms that offers such services on the market, however it is important that a reputable and secure provider is selected as it will be dealing with the business's most sensitive data. Some of the most famous fully managed payroll providers are Eagle Consulting, ADP, Ceridian, Genpact. NGA.

According to Turek ${ }^{40}$ there are several factors to consider when deciding on outsourcing the payroll function. The top three are the reliability of the provider of the service, the providers financial soundness and trustworthy and the type of payroll services the provider can offer.

Apte and Mason ${ }^{41}$ as well as Maurer and Mobley ${ }^{42}$ suggest that due to high standardisation, heavy administration and low interpersonal actions payroll is often seen as a prime candidate for outsourcing. The main motivation behind it is to reduce the operational cost of the organisation. According to Dickmann

39 Expert Payroll Services, http://payrollservices.expertmarket.co.uk (accessed: 14.02.2018).

40 W. Turek, Payroll Outsourcing Goes Beyond Payroll, "Payroll Supplement" 2008, no. 22, p. 16.

41 U. Apte, R. Mason, Global disaggregation of information-intensive services, "Management Science" 1995, vol. 41, no. 7, pp. 1250-1262.

42 R. Maurer, N. Mobley, Outsourcing: is it the HR department of the future?, "HR Focus" 1998, vol. 75 , no. 11 . 
and Tyson ${ }^{43}$ firms that invested less in payroll software, systems and equipment are more likely to outsource the payroll function. In addition, the availability of specialised skills is an important factor in some outsourcing decisions ${ }^{44}$. For some businesses the reason to look for outsourcing payroll is the work overload and the need to dispose routine work to concentrate on more "important" activities 45 .

In Poland payroll outsourcing companies offer three types of services ${ }^{46}$ :

- Payroll Online - a dedicated group of specialists will be responsible for payroll and contacts with Human Resources Departments;

- Payroll on-site - setting up a unit at the employer's premises to deliver payroll services;

- Payroll on-demand - dedicated specialist will perform regular or ad-hoc checks of the correctness of calculations of salaries, insurance premiums and taxes, in accordance with relevant regulations.

Paroling contract offered by Polish companies can include some or all of the listed below services:

- calculating remunerations for the employees hired on contractual basis;

- transferring remunerations and public law liabilities (e.g. tax) related to remunerations from company subaccounts into relevant bank accounts;

- reporting monthly information on calculated remuneration for the employees;

- calculating public law liabilities related to remunerations and preparation of ZUS (National Insurance) and PEFRON (State Disabilities Rehabilitation Fund) declarations;

- preparation of the information necessary for accounting in the form of group payroll considering management information required by employer;

- debt collection;

- preparation of yearly declarations: PIT 11, PIT 40, PIT 4R, PIT 8AR, ZUS IWA.

\section{Conclusion}

Fierce competition, limited resources and the necessity of cost cutting, force companies to look for new approaches to run their businesses. By entrusting some of the activities previously conducted in-house to an external provider, many companies reduce their operational costs. In the past Human Resources Management

43 M. Dickmann, S. Tyson, Outsourcing payroll...

44 K. Abraham, S. Taylor, Firms' use of outside contractors: theory and evidence, "Journal of Labour Economics" 1996, vol. 14, no. 3, pp. 394-424.

45 M. Dickmann, S. Tyson, Outsourcing payroll...

46 M.M. Stuss, Payrolling jako narzędzie rozwoju ZZL... 
mainly used outsourcing for training and coaching. However, in recent years more and more companies use payrolling to outsource some of the HRM function. The scope of the services offered by payrolling companies is extensive and businesses can select those services that suit them best, including the choice of outsourcing part or all of the payrolling functions. Outsourcing the payroll firstly allows the company to reduce operational costs. Secondly, to access to up-to-date technologies and expert knowledge, without engaging extensive resources. In addition, it helps to improve the quality of management and provides an opportunity to focus on the core aspects of the business. Finally, it permits better utilisation of company assets.

\section{References}

Abdul-Halim H., Che-Ha N., Geare A., The influence of business strategy on the decision to outsource human resource activities: a study of Malaysian manufacturing organizations, "Journal of Human Resource Costing and Accounting" 2009, vol. 13, no. 4, pp. 274-293.

Abraham K., Taylor S., Firms' use of outside contractors: theory and evidence, "Journal of Labour Economics" 1996, vol. 14, no. 3, pp. 394-424.

ADP, 2019, https://www.adp.com (accessed: 8.12.2019).

Aird C.L., Sappenfield D., IT the 'Enabler' of Global Sourcing, “Financial Executive” 2009, vol. 25, issue 5, pp. 62-65.

Apte U., Mason R., Global disaggregation of information-intensive services, "Management Science" 1995, vol. 41, no. 7, pp. 1250-1262.

Avery G., Outsourcing public health laboratory services: a blueprint for determining whether to privatize and how, "Public Administration Review" 2000, vol. 60, no. 4, pp. 330-337.

Bers J.S., Outsourcing: a deal or dilemma for FMs?, "Facilities Design \& Management” 1992, vol. 11, no. 3, pp. 54-57.

Brooks C., Choosing a Payroll Service: A Buying Guide for Businesses, 2017, March 17, http://www .businessnewsdaily.com/7477-choosing-payroll-service.html\#sthash.jlkXJBly.dpuf (accessed: 15.11.2019).

Cooke F.L., Shen J., McBride A., Outsourcing HR as a competitive strategy? A literature review and assessment of implications, "Human Resource Management" 2005, vol. 44, no. 4, pp. 413-432.

Crain N.V., Crain W.M., The impact of regulatory costs on small firms, US Small Business Administration, Office of Advocacy, 2010, September, https://www.sba.gov/sites/default/files/The $\% 20$ Impact $\% 20$ of\%20Regulatory\%20Costs $\% 20$ on\%20Small\%20Firms\%20(Full).pdf (accessed: 8.02.2017).

Delmotte J., Sels L., HR outsourcing: threat or opportunity?, “Personnel Review” 2008, vol. 37, no. 5, pp. 543-563.

Dickmann M., Tyson S., Outsourcing payroll: beyond transaction-cost economics, "Personnel Review" 2005, vol. 34, no. 4, pp. 451-467.

Domberger S., Fernandez P., Public-private partnerships for service delivery, "Business Strategy Review" 1999, vol. 10, no. 4, pp. 29-39.

Duggan B., Croy G., Should you outsource recruitment?, "Supply Management" 2004, vol. 3, no. 7, pp. 26-27. 
Expert Payroll Services, http://payrollservices.expertmarket.co.uk (accessed: 14.02.2018).

Fontes R., The outsource option, "Folio: The Magazine for Magazine Management" 2000, pp. 112-115.

Gilley K.M., Greer C.R., Rasheed A., Human resource outsourcing and organizational performance in manufacturing firms, "Journal of Business Research" 2004, vol. 57, no. 3, pp. 232-240.

Gonzalez R., Llopis J., Gasco J., Outsourcing and strategy in Spanish town halls: a field study, "Management Decision” 2013, vol. 51, no. 1, pp. 97-119.

Gotterdello D., Valverde M., Human resources management outsourcing in Spanish firms: evaluation over time and implication for devolution, "Intangible Capital" 2018, vol. 14(1), pp. 56-73.

Greaver M.F., Strategic Outsourcing. A Structured Approach to Outsourcing Decisions and Initiatives, Amacom, New York 1999.

Harler C., Opting for outsourcing, "Business Communications Review” 2000, vol. 30, no. 7, pp. 56-61.

IRIS, http://www.iris.co.uk/insight/iris-rti-managed-payroll-service/ (accessed: 20.12.2019).

John H., HR outsourcing in operation: critical success factors, "Human Resource Management International Digest" 2005, vol. 13, no. 3, pp. 39-42.

Kakabadse A., Kakabadse N., Sourcing: new face to economies of scale and the emergence of new organizational forms, "Knowledge and Process Management" 2000, vol. 7, no. 2, pp. 107-118.

Kalinowska K., Outsourcing jako metoda zarzqdzania przedsiębiorstwem, "Zeszyty Naukowe Polityki Europejskie, Finanse i Marketing" 2010, nr 3(52), pp. 253-264.

Klaas B.S., McClendon J.A., Gainey T.W., Outsourcing: the impact of organizational characteristics, "Human Resource Management" 2001, vol. 40, no. 2, pp. 125-138.

Kremic T., Tukeld O.I., Rom W.O., Outsourcing decision support: a survey of benefits, risks, and decision factors, "Supply Chain Management: An International Journal" 2006, vol. 11, no. 6, pp. 467-482.

Lepak D.P., Bartol K.M., Erhardt N., A contingency framework for the delivery of HR practices, "Human Resource Management Review" 2005, vol. 15, no. 2, pp. 139-159.

Lysons K., Gillingham M., Purchasing and supply chain management, Pearson, Prentice Hall, Harlow 2012.

Marquez J., Reducing costs a sore subject at HRO meeting, "Workforce Management" 2007, vol. 86, no. 9, pp. 7-8.

Maurer R. Mobley N., Outsourcing: is it the HR department of the future?, "HR Focus" 1998, vol. 75, no. 11.

Mehta A., Armenakis A., Mehta N., Irani F., Challenges and Opportunities of Business Process Outsourcing in India, "Journal of Labour Research" 2006, vol. 27, issue 3, pp. 323-338.

Miles R.E., Snow C., Designing strategic human resources systems, "Organizational Dynamics" 1984, vol. 13, no. 1, pp. 36-52.

Mise C., Payroll and HR outsourcing. Is it viable solution for tour organisation, CMA management, 2001 March, https://www.cmamanagement.com/uploaddocs/cma/website//Home.asp (accessed: 6.02.2019).

Nesheim T., Rørvik R., Exploring dilemmas in the relation between temporary help agencies and customer firms, "Personnel Review" 2013, vol. 42, no. 1, pp. 67-82.

Nesheim T., Olsen K., Kalleberg A.L., Externalizing the core: firms' use of employment intermediaries in the information and communication technology industries, "Human Resource Management" 2007, vol. 46, no. 2, pp. 247-264.

Oshima M., Kao T., Tower J., Achieving post-outsourcing success, "People and Strategy" 2005, vol. 28, no. 2, pp. 7-11. 
Parish R., Modern payroll outsourcing. A success story, "Nursing Home Magazine", 28 January 2008, https://www.iadvanceseniorcare.com/modern-payroll-outsourcing-a-success -story/ (accessed: 6.02.2019).

Penc J., Encyklopedia zarzq̨dzania, Agencja Wydawnicza Placet, Warszawa 2008.

Quinn J.B., Strategic outsourcing: leveraging knowledge capabilities, "Sloan Management Review" 1999, vol. 40, no. 4, pp. 9-21.

Rajagopalan N., Finkelstein S., Effects of strategic group membership and environmental change in senior management reward systems, "Strategic Management Journal” 1992, vol. 13, no. S1, pp. 127-141.

Remont R., Outsourcing HR - moda czy tendencja biznesowa?, 2017, http://www.outsourcing.com .pl (accessed: 8.02.2017).

Santos F.C., Integration of human resource management and competitive priorities of manufacturing strategy, "International Journal of Operations \& Production Management" 2000, vol. 20, no. 5, pp. 610-628.

Scott-Jackson W., Newham T., Gurney M., HR Outsourcing: the Key Decisions, Chartered Institute of Personnel and Development, London 2005.

Sen F., Shiel M., From business process outsourcing (BPO) to knowledge process outsourcing (KPO): Some issues, "Human Systems Management" 2006, no. 25, pp. 145-155.

Sharma A., Loh P., Emerging Trends in Sourcing of business services, "Business Process Management Journal" 2009, vol. 15, no. 2, pp. 149-165.

Sheehan C., Cooper B.K., HRM outsourcing: the impact of organisational size and HRM strategic involvement, "Personnel Review" 2011, vol. 40, no. 6, pp. 742-760.

Shelgren D., Why HR outsourcing continues to expand, "Employment Relations Today" 2004, vol. 31, no. 2, pp. 47-53.

Shih H.A., Chiang Y.H., Exploring the effectiveness of outsourcing recruiting and training activities, and the prospector strategy's moderating effect, "The International Journal of Human Resource Management" 2011, vol. 22, no. 1, pp. 163-180.

Stuss M.M., Payrolling jako narzędzie rozwoju ZZL we współczesnych przedsiębiorstwach, [in:] J. Engelhardt, M. Brojak-Trzaskowska, M. Porada-Rochoń (eds), Nowoczesne przedsiębiorstwo, "Zeszyty Naukowe Uniwersytetu Szczecińskiego" 2009, no. 572, pp. 275-281.

Surepayroll, www.surepayroll.com (accessed: 11.12.2019).

Total Jobs, www.Total Jobs.com (accessed: 21.12.2019).

Trocki M., Metoda restrukturyzacji działalności gospodarczej, Polskie Wydawnictwo Ekonomiczne, Warszawa 2001.

Turek W., Payroll Outsourcing Goes Beyond Payroll, "Payroll Supplement" 2008, no. 22, p. 16.

Wright L., Market viewpoint: outsourcing is a no-claims bonus, "Insurance Brokers' Monthly \& Insurance Adviser" 2001, vol. 51, no. 1, pp. 12-15. 


\section{Abstract}

The intensified globalization process, the fast-growing development of Information Technology, and the necessity to reduce operating costs, force companies to look for more efficient ways of using resources. Outsourcing some of the operation to external providers can be a good way to reduce cost. Payroll outsourcing can offer various benefits, such as lowering operational costs, access to the newest technologies and expertise without involving extensive use of resources. This is only possible if a reliable provider that is financially sound and trustworthy is available. This paper investigates the benefits that can be gained by outsourcing the payrolling function. Outsourcing will be defined and its benefits discussed, followed by an analysis of payrolling within Human Resource Management (HRM) outsourcing. Finally, the benefits of outsourcing of the payrolling function will be presented.

Keywords: outsourcing, outsourcing HR, Human Resource Management, payrolling 